\title{
The Storage Effect on Fuel Properties and Emission for Variety Biodiesel Blends
}

\author{
Yusof Humairak ${ }^{2, a}$, Noreffendy Tamaldin ${ }^{1,2, b^{*}}$, M.F.B. Abdollah ${ }^{1,2, c}$, M.F. Ali ${ }^{2}$ \\ and A. Khalid ${ }^{3, d}$ \\ ${ }^{1}$ Centre for Advanced Research on Energy (CARe), Universiti Teknikal Malaysia Melaka76100 \\ Durian Tunggal, Melaka, Malaysia \\ ${ }^{2}$ Faculty of Mechanical Engineering, Universiti Teknikal Malaysia Melaka76100 Durian Tunggal, \\ Melaka, Malaysia
}

${ }^{3}$ Faculty of Mechanical and Manufacturing Engneering, Universiti Tun Hussein Onn Malaysia,Parit Raja, Batu Pahat, 86400 Johor, Malaysia.

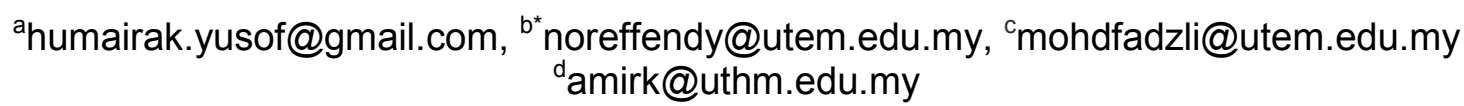

Keywords: Biodiesel, high blending ratio, storage, properties, emission.

\begin{abstract}
In this paper, storage effect on biodiesel properties for high blending ratio and the emission are evaluated. The blend level of biodiesel is denoted as B, followed by the percentages of pure biodiesel. The samples used are conventional diesel (STD), B80, B90 and B100 were stored at ambient temperature $\left(24{ }^{\circ} \mathrm{C}\right)$ for nine week. The properties of biodiesel which are acid value, flash point, viscosity, density and water content were measured according to ASTM D6751 biodiesel fuel standard. Results show there are no significant effects on it properties while stored in long duration at ambient temperature. Meanwhile, increasing biodiesel ratio is found to enhance the combustion process, resulting in decreased the $\mathrm{HC}$ for emissions.
\end{abstract}

\section{Introduction}

Malaysia Palm oil industry is the fourth contributor to the national economy. Currently, Malaysia is the world's largest exporter and the second largest production after Indonesia for crude oil [1]. The palm oil had gone through trans-esterification process where palm oil and alcohol (ethanol/methanol) are mixed together with the presence of catalyst $(\mathrm{NaOH} / \mathrm{KOH})$ to produce methyl ester (biodiesel) and glycerin [2]. Biodiesel can be considered as an alternative fuel due to the fact that it can be used in diesel engine [3-5]. In addition to that, biodiesel also is a type of renewable and green source of fuel since it can be produced from living organism and emits less harmful greenhouse gasses upon combustion [7]. To demonstrate the potential of biodiesel fuel, the investigation will be on the storage effect to the biodiesel high blending ratio properties and also its emission.

Pure biodiesel (B100) can be used directly as fuel in diesel engine. However, it can also be blended with the standard petroleum fuel by percentage to create a hybrid fuel. Biodiesel blend is denoted as $\mathrm{B}$ and follow by the percentage of the biodiesel inside the fuel. Biodiesel low blending ratio B5 (5\% of biodiesel) till B20 (20\% of biodiesel) can be used in the engine without modification because both have meet the fuel specification that can be use in diesel engine. However high blending ratio of biodiesel cannot be used directly to the diesel engine as it contains high level of water content. The high level of water content can causes problems to the engine such as fuel filter plugging, corrosion to the engine compartment, fuel degradation and also microbial growth [8]. The problems arises can affect the total performance of the engine itself [8-9]. For an ideal combustion reaction in the diesel engine, the combustion of fuel in oxygen will produces water and carbon dioxide $\left(\mathrm{CO}_{2}\right)$, however the ideal reaction is unlikely to happen in real situation. In real combustion process, incomplete combustion will occur due to the lack of oxygen to 
complete the chemical reaction during combustion process. The incomplete combustion process will produce harmful greenhouse gasses $\left(\mathrm{NO}_{\mathrm{x}}, \mathrm{CO}\right.$ and $\left.\mathrm{HC}\right)$ which are poisonous and contribute to global warming [7]. The usage of biodiesel low blending ratio has been proven to reduce the harmful emission gases emits by the diesel engine and can be use without modification to the engine [10].

Currently, there are many researches regarding biodiesel that have been conducted to reduce the dependability of petroleum fuel and to replace it with more environmental friendly type of fuel. According to Zakaria et. al. (2014), biodiesel that stored in long storage duration can affect the oxidation stability, fuel degradation and microbial growth [8]. Moreover, if the fuel is exposed to the air while storing, the degradation of fuel properties will increase rapidly. Among the fuel properties that was studied in this research are acid value, water content, flash point, density and kinematics viscosity. Each of the properties will affect the performance of the engine in a certain degree.

\section{Experiment Procedure}

There are four samples which are standard diesel, B80 (80\% of B100), B90 (90\% of B100) and biodiesel (B100). The samples were blended at $270 \mathrm{rpm}$ for an hour and heated around $70{ }^{\circ} \mathrm{C}$ [11]. According to biodiesel handling guide, biodiesel temperature should be above it cloud point while blending to avoid fuel appearing cloudy. The cloudiness of the fuel indicates that the fuels is in low quality and contain high viscosity and water content [12]. All samples were stored for nine weeks at $24{ }^{\circ} \mathrm{C}$. The fuel properties (acid value, flash point, density and kinematic viscosity) for all samples have been measured and recorded according to ASTM D6751.

To determine the amount of acid value in the samples, a color indicator titration method was used. One gram of each samples was used and titrated with potassium hydroxide $(\mathrm{KOH})$ or sodium hydroxide $(\mathrm{NaOH})$ solution individually. The titration will cause the sample to change in violet color. The process will be done until the sample maintain the violet color for more than 30 seconds. The flash point of all the samples was determined by using Setaflash Series 3 Closed Cup Flash Point. The instrument measures the flash point temperature for every sample. Ignition mechanism was applied where at the maximum temperature of the sample, a 'pop' sound appeared and the flash temperature is automatically recorded. The density of all the samples was measured using hydrometer by immersing the hydrometer in $100 \mathrm{ml}$ measuring cylinder, each of the samples was added into the measuring cylinder individually until the hydrometer float and the reading was recorded. The kinematic viscosity was measured using DV Pro viscometer. The instrument will record the viscosity of the samples. Emission test was measured using gas analyzer and single cylinder diesel engine. The engine runs at $3500 \mathrm{rpm}$ to $1500 \mathrm{rpm}$. The data appear in gas analyzer screen was taken every 30 seconds. The data for hydrocarbon produced by the engine was collected and analyzed.

\section{Result and Discussion}

Properties for all samples was measured and recorded after blending process. Table 1 below shows results of fuel properties for standard diesel fuel, B80, B90 and biodiesel at ambient temperature. The properties for all samples show that the value increases with the rising of the biodiesel blending ratio. As stated in the theory, the kinematic viscosity of the fuel is inversely proportional to its density. This verify that when density increases, kinematic viscosity will decrease as shown in Table 1.

Other than that, Table 1 also shows that increment of blending ratio will lead to the increment of the flash point. This relationship occur due to the high number of moisture that are present in the biodiesel. At the same time, the acid value content in biodiesel also shows increment because of the increasing fatty acid content that are present in the biodiesel as the biodiesel blending keep on rising. 
Table 1: Properties for all samples at $24^{\circ} \mathrm{C}$

\begin{tabular}{|l|c|c|c|c|}
\hline \multirow{2}{*}{ Fuel type } & \multicolumn{4}{|c|}{ Properties } \\
\cline { 2 - 5 } & Density $\left(\mathrm{g} / \mathrm{cm}^{3}\right)$ & $\begin{array}{c}\text { Kinematic } \\
\text { viscosity }(\mathrm{mm} 2 / \mathrm{s})\end{array}$ & Flash point $\left({ }^{\circ} \mathrm{C}\right)$ & $\begin{array}{c}\text { Acid value } \\
(\mathrm{mgKOH} / \mathrm{g})\end{array}$ \\
\hline STD & 0.8337 & 3.0 & 80.0 & 0.2044 \\
\hline B80 & 0.8654 & 4.4 & 113.0 & 1.9600 \\
\hline B90 & 0.8684 & 4.1 & 123.0 & 4.3400 \\
\hline B100 & 0.8729 & 3.9 & 124.0 & 5.1800 \\
\hline
\end{tabular}

The effect of storage duration on biodiesel acid value and flash point are evaluated. If high acid value content present in the fuel, corrosion could happen in the engine and thus damaging the engine components in long-term usage [9]. On the other hand, if the fuel has low flash point temperature (below $60{ }^{\circ} \mathrm{C}$ ), the fuel is hazardous to be used, handled and stored properly. Therefore the biodiesel with high blending ratio is investigated as reference.

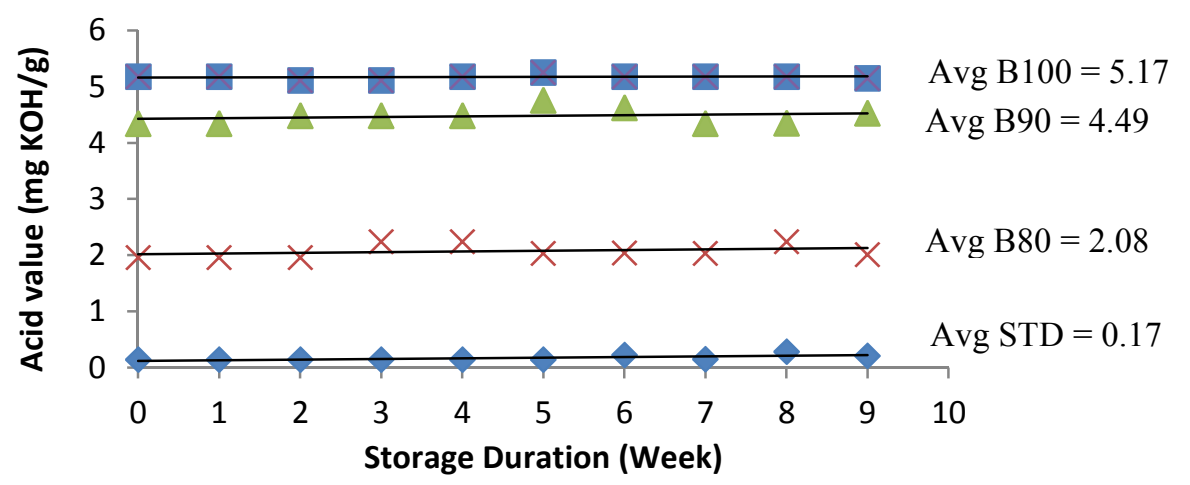

Fig. 1, Acid Value (mg KOH/g) against Storage Duration (week)

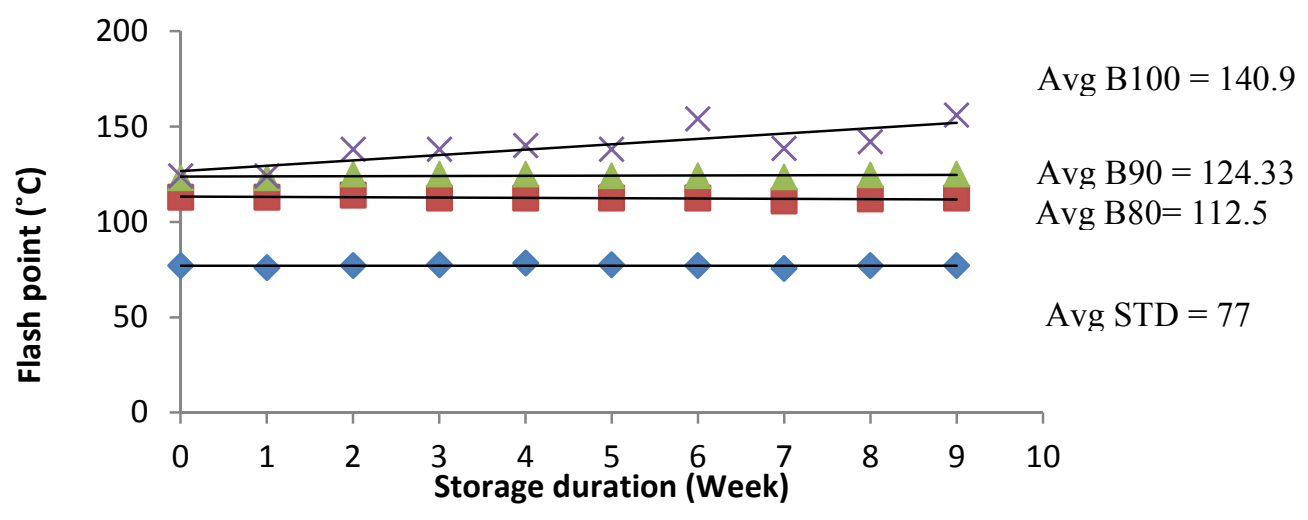

Fig. 2, Flash point $\left({ }^{\circ} \mathrm{C}\right)$ against storage duration (week)

Fig. 1 shows the graph of acid value against storage duration. The figure shows that all the samples are stable as the storage time keep on increases. The figure also shows that there are no significant effects to the acid value when storage duration increases up to the ambient temperature $\left(24^{\circ} \mathrm{C}\right)$. There is no oxidation or degradation occurs to the fuel when it stored at $24{ }^{\circ} \mathrm{C}$ which indicate that the fuel could maintain its quality from degrading [13-14].

Fig. 2 shows the flash point graph against storage duration. As the time storage period increases, all samples shows near to constant flash point values. The data verify that all the samples can maintain their chemical bonding as the time gradually increases at $24{ }^{\circ} \mathrm{C}$ temperature except for 
B100. It happens because B100 samples are unstable and degradation happens to the fuel while it stored.

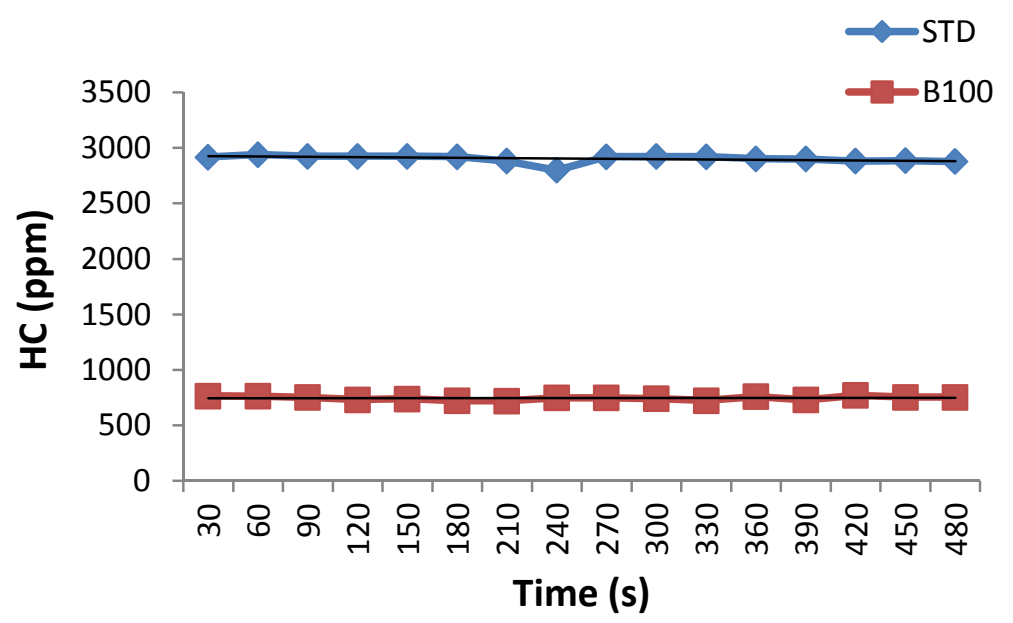

Fig. 3, Graph of Hydrocarbon (ppm) versus Time (s) for standard diesel and B100

Fig. 3 shows the graph of hydrocarbon emits by the single cylinder diesel engine against time. The figure explains the relationship of the HC gases emits by both samples (standard diesel (STD) and biodiesel (B100)) when burned in single cylinder diesel engine. The results shows that the HC gas for standard fuel is higher compared to the biodiesel. This is due to the fact that biodiesel contain higher oxygen level than the standard fuel. Oxygen is needed to complete the combustion reaction and thus reducing the incomplete emission gases from the engine. For the incomplete combustion, the reaction will produce carbon monoxide $(\mathrm{CO})$, hydro carbon $(\mathrm{HC})$, water and $\mathrm{CO}_{2}$.

\section{CONCLUSION}

This paper presents the effect of storage time on biodiesel properties and emission. Important conclusions drawn from this work include:

i. Increasing the blending ratio of biodiesel fuel corresponding to increase of acid value. This acid value increment is due to higher composition of methyl ester in biodiesel fuel.

ii. There are no significant effect to the acid value and flash point in long storage time. It shows that the samples are stable when it stored in the dark place and without present of light. Further, it helps the biodiesel from degradation.

iii. Biodiesel decreasing the $\mathrm{HC}$ content in emission gases compared to the diesel petrol. In summary, this study has contributed to our knowledge about long storage duration and the effect to the biodiesel properties. In particular, further research should be conducted on the effect of biodiesel high blending ratio to the engine performance and emission.

\section{REFERENCES}

[1]M. Chin, "Biofuels in Malaysia," 2011.

[2] D. Sebayang, E. Agustian and A. Praptijanto, Transeterification of biodiesel from waste cooking oil using ultrasonic technique, in International Conference on Environment, 2010.

[3]B. Tesfa, R. Mishra, F. Gu, and A. Ball, Combustion characteristics of CI engine running with biodiesel blends, in International Conference on Renewable Energies and Power Quality, 2011. 
[4]A. Khalid, S. A. Osman, M. N. M. Jaat, N. Mustaffa, S. M. Basharie, and B. Manshoor, Performance and emissions characteristics of diesel engine fuelled by biodiesel derived from palm oil, Appl. Mech. Mater., 315 (2013, Apr.)517-522.

[5] C. Pattamaprom, W. Pakdee and S. Ngamjaroen, Storage degradation of palm-derived biodiesels: its effects on chemical properties and engine performance, Renewable Energy, vol. 37, no. 1, pp. 412-418, 2012.

[6] Y. Gao, J. Deng, C. Li, F. Dang, Z. Wu and L. Li, Experimental study of the spray characteristics of biodiesel based on inedible oil, Biotechnology Advances, vol. 27, no. 5, pp. 616624, 2009.

[7] NREL (National Renewable Energy Laboratory), (2009). Biodiesel Handling and Use Guide. Retrieved September 23, 2013 from, http://www.nrel.gov/vehiclesandfuels/pdfs/43672.pdf.

[8] H. Zakaria, A. Khalid, M. F. Sies and N. Mustaffa, Overview effect of biodiesel storage on properties and characteritics, Applied Mechanics and Materials, vol. 465 - 466, pp. 260-264, 2014.

[9] H. Zakaria, A. Khalid, M. F. Sies, N. Mustaffa and B. Manshoor, Effect of storage temperature and storage duration on biodiesel properties and characteristics, Applied Mechanics and Materials, vol. 465 - 466, pp. 316-321, 2014.

[10] M., Bowman, D., Hilligoss, S. Rasmussen, and R. Thomas., (2006) Biodiesel: a Renewable and Biodegradable Fuel Hydrocarbon Processing. Retrieved September 23, 2013 from, http://www.perkinelmer.com/pdfs/downloads/ATL_BiodieselHydrocarbProcessing.pdf .

[11]A. Khalid, N. Tamaldin, M. Jaat, M.F.M. Ali, B. Manshoor and I. Zaman, Impacts of biodiesel storage duration on fuel properties and emissions, International Tribology Conference Malaysia, vol. 68, pp. 225-230, 2013.

[12] H. Ge, J. Scharffbillig, C. Ahlberg and E. Clark, A Biodiesel Blend Handling Guide. 2009. Retrieved September 2013 from, www.mda.state.mn.us/biodiesel.

[13]M. Shahabudin, M. A. Kalam, H. H. Masjuki, M. M. K. Bhuiya and M. Mofijur, An experimental investigation into biodiesel stability by means of oxidation and property determination, Energy, vol. 44, no. 1, pp. 616-622, Aug. 2012.

[14] A. Obadiah, R. Kannan, A. Ramasubbu and S.V. Kumar, Study on the effect of antioxidants on the long-term storage and oxidation stability of pongamia pinnata (1.) pierren biodiesel, Fuel Processing Technology, 99 (2012) 56-63. 